\title{
Reproductive ecology and behaviour of the Puerto Rican Nightjar Caprimulgus noctitherus
}

\author{
FRANCISCO J. VILELLA
}

\author{
A mi amigo Ted: \\ "En la vida todo es ir \\ a lo que el tiempo deshace, \\ sabe el hombre donde nace \\ y no donde va a morir" \\ J. A. Corretjer (Puerto Rico)
}

\section{Summary}

The reproductive ecology and behaviour of the endangered Puerto Rican Nightjar Caprimulgus noctitherus was studied at the Guánica Forest, located in south-western Puerto Rico. From 1985 to 1987 a total of 23 nightjar nests were located. Nests were initiated between 24 February and 2 July. Nightjar males were mostly responsible for parental duties. An elaborate nest-relief ceremony was discovered for this species. Courtship and laying activities were most common during the new moon and last quarter phases. Hatching dates were centred 3-5 days around the first quarter and during full moon. A total of $87 \%$ of the nests were successful in producing at least one fledgling. Locomotory activity of radio-tagged nightjar males was higher during periods of twilight, and averaged $61.5 \mathrm{~m} /$ movement. Area of primary utilization (i.e. home range) averaged $5.2 \mathrm{ha} / \mathrm{nightjar}$ during the period of transmission. A large portion of the species's current range is privately owned forestland that could be subjected to changes (i.e. deforestation), rendering it useless for nightjars. The sedentary nature and nesting habits of this species make it particularly sensitive to the physical and ecological alteration of mature dry forest. Conservation of existing reserves, reforestation of disturbed areas with native and selected plantation species, and acquisition of privately owned tracts of mature dry limestone forest will help to insure the long-term survival of the species throughout its range.

La ecología reproductiva del Guabairo Pequeño de Puerto Rico Caprimulgus noctitherus, conocido comúnmente como guabairo, se estudió en el bosque de Guánica, localizado en el suroeste de Puerto Rico. Del $1985^{-1987}$ se localizaron un total de 23 nidos. La temporada reproductiva se extendió desde el 24 de febrero hasta el 2 de julio. El macho de la especie es mayormente responsable por el cuidado parental. Se descubrió una ceremonia altamente elaborada para el relevo en el nido. La actividad de cortejeo y el comienzo de los nidos era mas común durante las fases de luna nueva y cuarto menguante. Las fechas de eclosión se encontraban de $3^{-5}$ días alrededor del cuarto creciente y la luna llena. Un $87 \%$ de los nidos fueron exitosos en producir por lo menos 
un volantón. La actividad locomotora de machos de guabairo equipados con radiotransmisores fue más alta durante el período crepuscular y promedió $61.5 \mathrm{~m} /$ movimiento. El área de utilización primaria promedio fue de 5.2 ha/guabairo durante el período de transmisión. Una parte considerable de la distribución del guabairo aún se encuentra en áreas bajo propiedad privada, podiendo sufrir cambios dramáticos en la composición del paisaje (i.e. desmonte). La naturaleza sedentaria de esta especie y sus hábitos reproductivos la hace particularmente vulnerable a la alteración física y ecológica del bosque seco. La conservación de las unidades de conservación existentes, la reforestación con especies de árboles nativos y algunas especies de plantación, y la adquisición de áreas privadas de bosque seco maduro ayudará a asegurar la sobrevivencia a largo plazo de la especie a través de su distribución geográfica.

\section{Introduction}

The Puerto Rican Nightjar Caprimulgus noctitherus, hereinafter termed Nightjar, is endemic to coastal dry and lower montane forests of south-western Puerto Rico. This single-island endemic is presently listed by the Puerto Rico Department of Natural and Environmental Resources (DNER), the U.S. Fish and Wildlife Service (FWS), and the International Union for Conservation of Nature (IUCN) as endangered throughout its range (Diaz 1983, Johnson 1987, Collar et al. 1992).

Caprimulgids are ground-nesters usually associated with forested habitats. The nocturnal habits and cryptic plumage of caprimulgids make them difficult to study (Lack 1930, Raynor 1941, Fowle and Fowle 1954, Reynard 1962, Babcock 1975). The available information on the reproductive ecology of the Nightjar is also very limited. In total, eight accidentally discovered nests between 1970 and 1984 have been reported. These have provided the only published information, mostly descriptive accounts, on breeding chronology and natural history (Kepler and Kepler 1973, Noble et al. 1986). Here I report on the reproductive ecology and behaviour of the Nightjar.

\section{Study site}

The study was conducted in the Guánica Forest, a 3,300-ha UNESCO Biosphere Reserve of coastal dry limestone forest located in south-western Puerto Rico. Data on the reproductive ecology of the Nightjar were collected in the section of Guánica Forest east of Guánica Bay, hereinafter termed Guánica Forest. There, the coastal dry forest has been protected from human disturbance for over 70 years; however, during the past century large portions of the area were selectively lumbered for charcoal production and cleared for grazing and farming.

The climate of Guánica Forest is dry, particularly from January to May when precipitation does not exceed $30 \mathrm{~mm}$, and approximately $35 \%$ of the trees are deciduous. The Guanica Forest is classified in the Subtropical Dry Forest Life Zone (Ewel and Whitmore 1973). The dominant families are Fabaceae, Euphorbiaceae, Myrtaceae, and Myristicaceae (Lugo et al. 1978).

\section{Methods and materials}

I collected data on the reproductive ecology of the Nightjar within Guánica Forest along all existing paths and vehicle roads from late February to July 
during 1985-1987. Trails ranged from small footpaths $0.5 \mathrm{~m}$ across to paved roads about $3 \mathrm{~m}$ wide. All locations at which males were estimated to be singing within $75 \mathrm{~m}$ of the trail during crepuscular hours were marked with flagging tape. At locations where several adjacent males were simultaneously singing, playback recordings were utilized to estimate the actual number of singing males. Male Nightjars were identified by the presence of white markings on the tip of the tail feathers. Female Nightjars were never observed singing.

Singing locations were marked throughout the breeding season. Information on date, time, area, and activity was recorded. Flags were removed the following year at the beginning of the field season. Searches were conducted by groups of 3-7 workers between 1985 and 1987 to locate nests in the vicinity of flags. Locations were searched by having the workers line up at $50 \mathrm{~m}$ intervals, using the flag as the midpoint of the area to be searched. Before starting, all members of the crew would cover their shoes and hands with extract from the Aloe vera plant to mask human odour. This exotic was chosen to mask odour because it has long become established over much of the forest and has a strong smell. The group would then slowly search as far as the terrain would allow, looking for Nightjar signs. If no signs were found after $30-40$ minutes of searching, the crew would return to the trail and search the side opposite the flag in the same manner. Once the area had been searched, the outcome was recorded (nothing, roosting bird, roosting pair, incubating bird, brooding bird) and the area searched recorded on a map drawn to scale from topographic quadrangles and aerial photographs.

When a Nightjar was located with eggs and/or chicks, flagging was placed directly above the spot where the adult Nightjar was located. For a given year, a standard colour type was utilized to mark all the nest-sites as well as their locations on the trails throughout the study. All nests were monitored by visiting every other day. Eggs and chicks were weighed with a Pesola spring scale and measured with calipers. Laying and hatching dates were obtained by back-calculating eggs at hatching and age of young when discovered, respectively. Chicks were individually marked on the forehead with vegetable dye.

A sample of 10 nests was closely monitored from portable observation blinds during the study. The blinds were built from camouflaged material and vegetation, and placed approximately $7 \mathrm{~m}$ from the nest. A light amplifying NOCTRON V Nightscope (VARO Inc.), equipped with a $135 \mathrm{~mm}$ lens, was used to monitor the nest during hours of darkness. A Star-Tron IR Pulser (Star-Tron Corp.) infra-red light source was placed in the immediate vicinity of the nest to improve light conditions during the observation periods. The blinds were visited every other day and observations recorded during one of three periods at night (18h30-21hoo, 23hoo-01hoo, 04h30-06h30). More than one blind would frequently be visited on the same night. A headlamp with a red filter was worn when entering and leaving the blind to minimize disturbance.

The movements of chicks and juvenile Nightjars from these 10 nests were documented by relocating marked individuals during searches similar to the ones conducted to locate nests. Chicks and juveniles were captured by hand or with the aid of a fish-landing net (see below). Weight and condition of the chicks were recorded on every visit. Movements and locations were recorded on a map drawn to scale. 
Radio telemetry was utilized to investigate the movements of nesting Nightjars. Nesting birds were captured using two techniques. The first involved use of a modified fish-landing net $(50 \times 30 \mathrm{~cm})$ with a $1 \mathrm{~m}$ deep pocket. The procedure was to approach to within $1 \mathrm{~m}$ of a nesting bird, and then place the net over the bird to capture it. Three modified mist-nets $1-2 \mathrm{~m}$ high and $10 \mathrm{~m}$ long arranged in a U-shape around the nesting adult, were used for the second capture technique. Two persons would walk towards the nest from the open side and attempt to flush the bird into the nets.

Each captured bird was slipped head-first into a small cloth bag before being banded, measured and weighed. Standard measurements were taken with a caliper to the nearest millimetre. Length of the longest rictal bristle on each side of the bill was also recorded. A high-frequency (222.00-223.00 $\mathrm{MHz}$ ) miniature radio-transmitter (Wildlife Materials Inc.) weighing $1 \mathrm{~g}$, with a $10 \mathrm{~cm}$ whip antenna (range $\leqslant 800 \mathrm{~m}$, battery life $\leqslant 30$ days) was glued dorsally to the rachis of the central rectrix and fastened with nylon fishline. After allowing the glue to dry for 3-5 minutes, the bird was released within the area of the nest-site.

Locations were obtained during crepuscular and night hours using a high-frequency Falcon Five receiver and a hand-held 3-element Yaggi antenna (Wildlife Materials Inc.). Due to the use of a high-frequency radio source, a model APS-164 Scat-Scanner (Wildlife Materials Inc.) was utilized to separate signals by pulse rate. Locations of tagged birds were taken from dusk to dawn every hour for the first two days. Thereafter, locations were taken daily from 19hoo-21hoo, 23h30-24h3o, and o5hoo-o7hoo for the duration of transmission.

A $\chi^{2}$-test was used to test for synchrony between lunar month and reproductive cycle (Steel and Torrie 1980, Mills 1986). Harmonic means were obtained for distance covered by movement and number of movements for each radio-tagged adult and colour-marked young (Dixon and Chapman 1980). A $\chi^{2}$-test on the pooled telemetry data was used to test for differences in number of movements and distances covered between the time-periods sampled. A Student's $t$-test was used to test movement and distance data between dawn and dusk periods (Steel and Torrie 1980). All statistical analysis ( $x=0.05$ ) was conducted using the Statistical Analysis System for microcomputers (Joyner 1985).

\section{Results}

Some 2,717 person-hours were invested searching approximately $30.8 \mathrm{~km}$ of trails on Guánica Forest, nearly $17 \%$ of the forest ( $473.6 \mathrm{ha}$ ), during 1985-1987. Some 85-89 locations of different singing Nightjar males were flagged per year.

A total of 23 Nightjar nests were located during the study. Nests were numbered and their locations mapped as they were located during 1985 (N1N9), 1986 (N10-N13), and 1987 (N14-N23) (Figure 1). At nest-sites, breeding pairs were observed during all stages of the nesting cycle, from recently initiated nests to adults brooding immature fledglings.

\section{Breeding biology and behaviour}

The Nightjar exhibits chorusing behaviour with respect to singing: one bird's vocalization elicits responses from nearby individuals (Reynard 1962, Kepler 


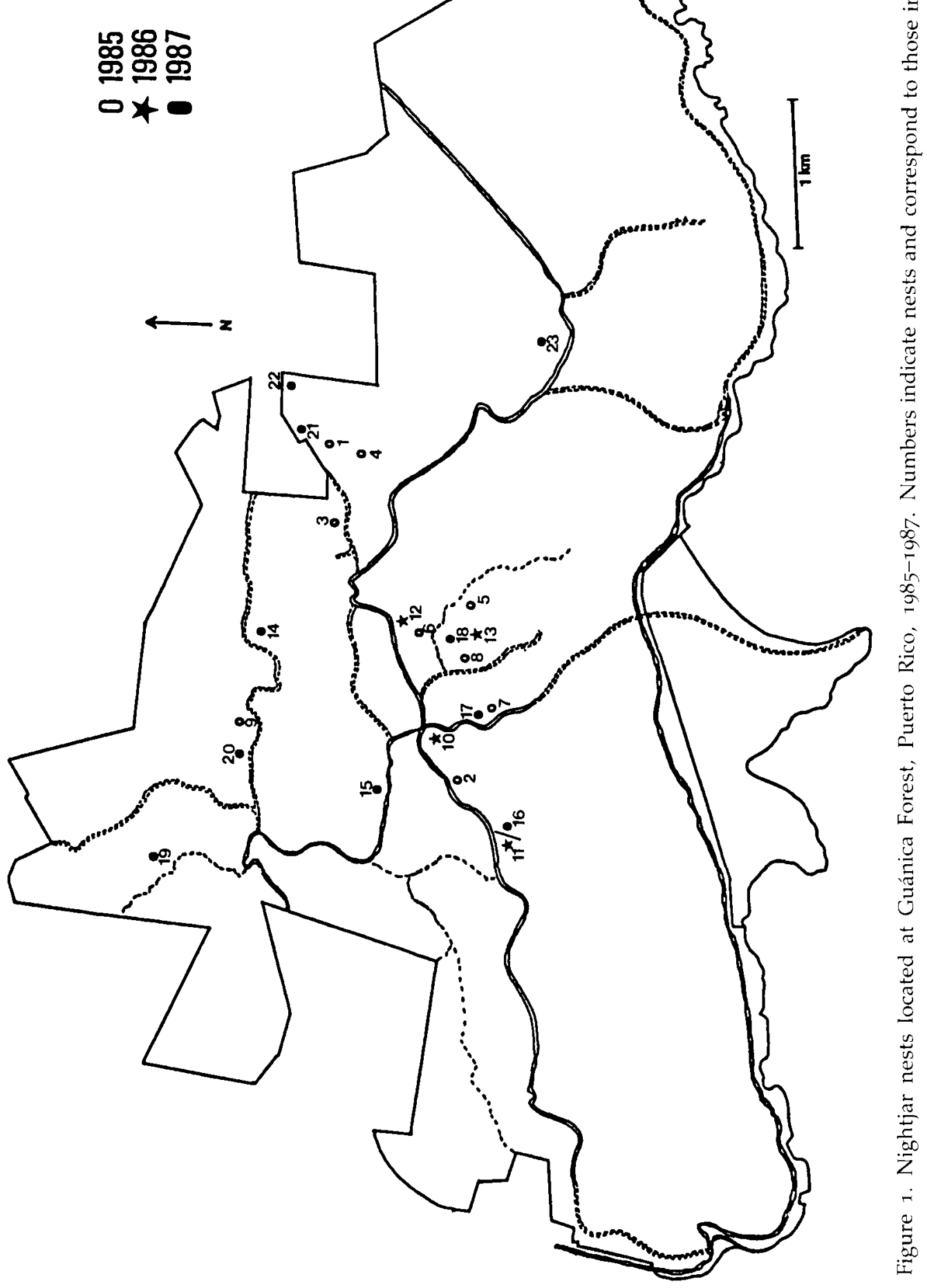




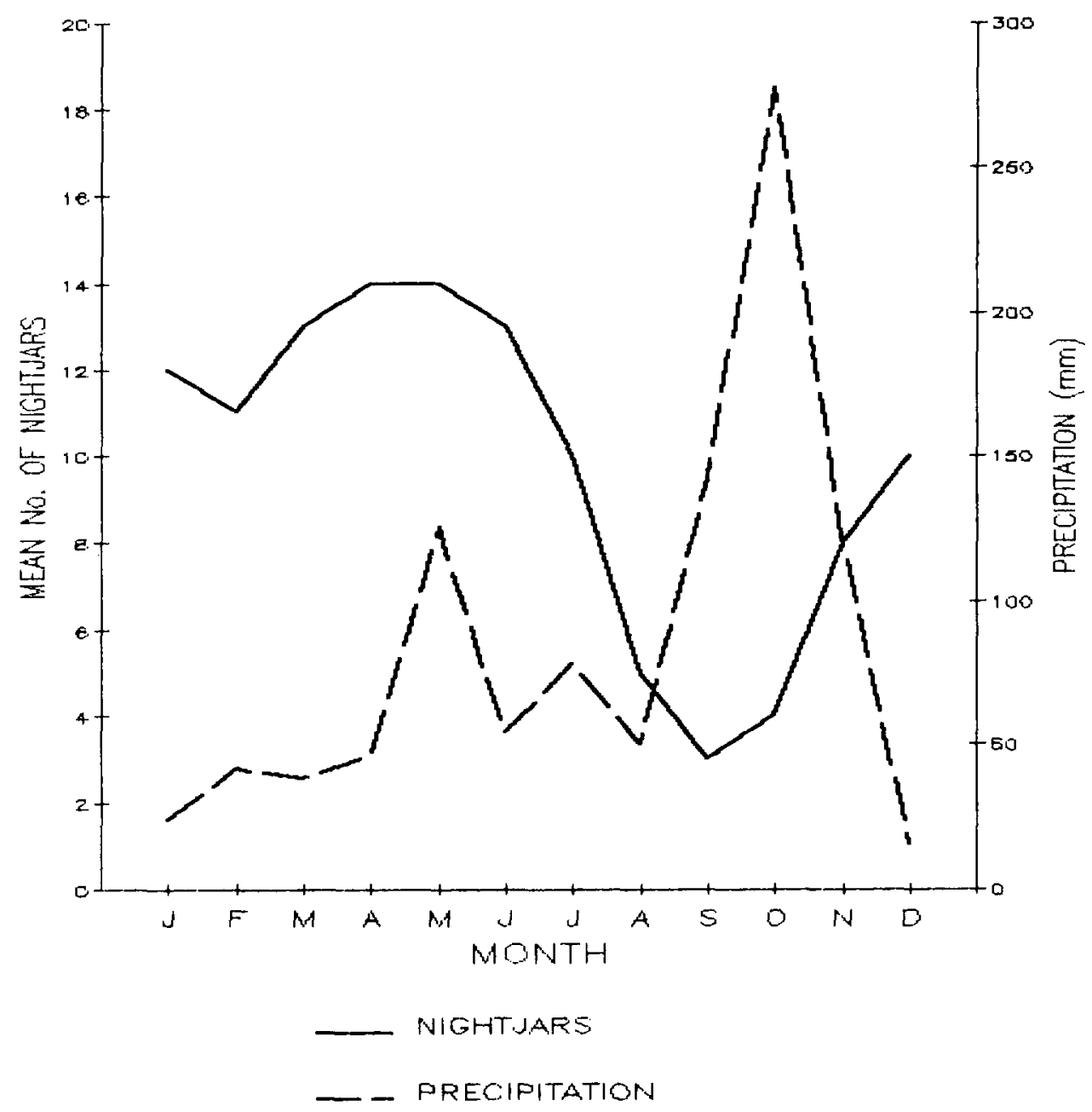

Figure 2. Mean number of singing Nightjars during peak hours and precipitation by month at Guánica Forest, Puerto Rico, during 1986-1987.

and Kepler 1973). Chorusing behaviour could be elicited by taped songs. In areas where neighbouring males were simultaneously singing, playbacks would elicit a group response that allowed a more accurate estimation of the number of birds involved.

Singing occurred during all months of the year, although the number of singing males and the intensity of singing varied seasonally. In addition, an annual pattern was noted in the number of individuals singing during crepuscular, peak singing hours (Figure 2). Generally, singing activity was at a minimum in September and October. Thereafter, it increased until it reached a peak during April and May. From 50 bimonthly dawn and dusk counts in 19861987 under ideal conditions along trails 7 and 14 (for methods and trail locations 


\section{Month}

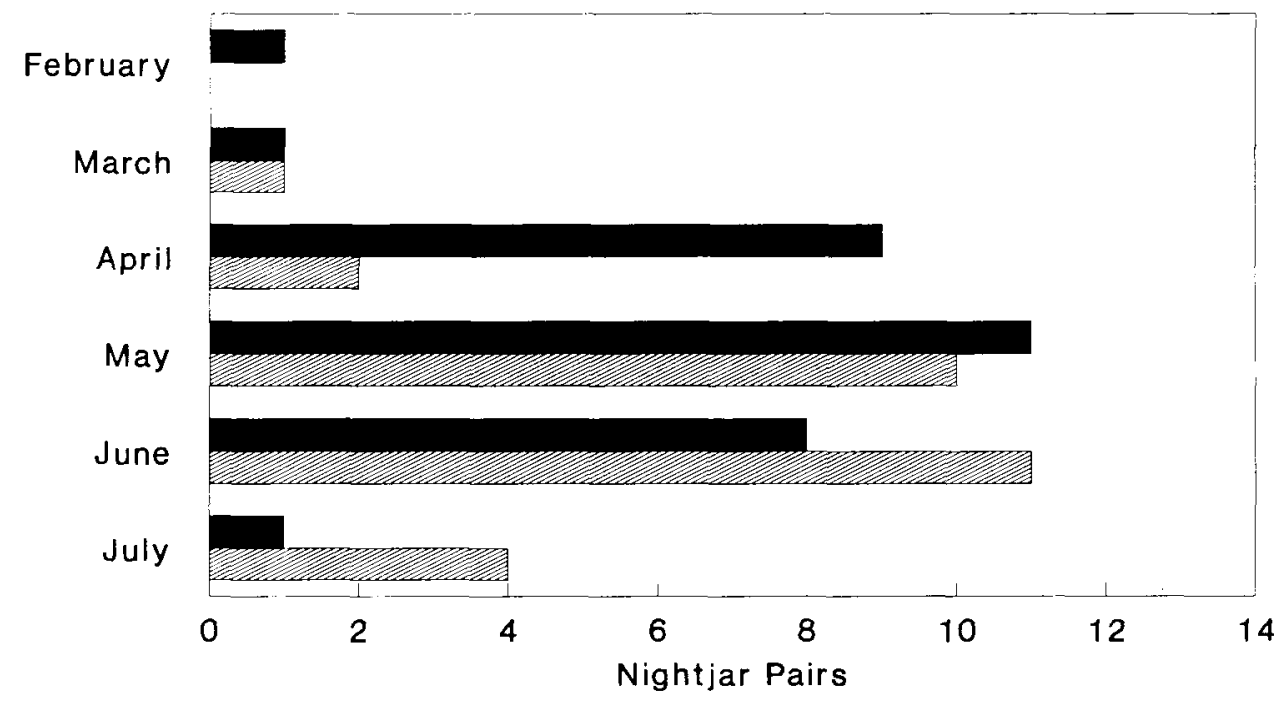

Incubating Pairs 装竞 Brooding Pairs

Figure 3. Temporal distribution of the Nightjar's breeding season. Sample $(n=31)$ includes nests of the present study (23) and all previously reported (8).

see Vilella and Zwank 1993a), a decrease was found in the number of singing Nightjars during late July to early August. This reduction of vocalization coincided with the end of the Nightjar's breeding season and the beginning of the rainy season at Guánica Forest. As calling rate increased during the latter half of December, territorial encounters between neighbouring males became more frequent. Approximately three days before laying, females roosted during the day on the forest floor within to $\mathrm{m}$ of where the eggs were subsequently deposited.

Nightjar breeding pairs initiated nests (first egg laid) between 24 February and 1 July (Figure 3), with the peak of activity from April through June. This three-month period includes 91\% (25 of 31) of the Nightjar's known nesting dates. Most eggs were deposited during the last quarter and new moon phases $\left(\chi^{2}=13.7\right.$, d.f. $\left.=3, p<0.001\right)$. The female Nightjar does not construct a nest as such, she merely lays the eggs directly on the leaf-litter. I use the word "nest" when referring to an adult Nightjar that is either incubating eggs or brooding young. Nests were never found in exposed areas or clearings. Clutches consisted of 1 or 2 eggs; $83 \%$ (19 of 23) of the nests located were two-egg clutches (Table 1). The eggs have been described by Kepler and Kepler (1973) as buffy-brown with numerous brownish purple spots over the entire surface; however, I found some degree of variability in the amount of spotting $(n=40)$, with some eggs being paler and less speckled than others. Eggs appeared only moderately cryptic on the substrate; however, the incubating adult provided excellent concealment through its cryptic plumage.

Incubation in caprimulgids has previously been reported to be almost exclusively performed by females. Males rarely incubate during the day (Lack 
Table 1. Nightjar nests located during $1985-1987$ on Guánica Forest, Puerto Rico.

\begin{tabular}{|c|c|c|c|c|c|}
\hline Nest $^{1}$ & $\begin{array}{c}\text { Distance to } \\
\text { trail }(m)\end{array}$ & Habitat type & $\begin{array}{l}\text { (Day/Month/Year) } \\
\text { Nest started }\end{array}$ & $\begin{array}{l}\text { Clutch } \\
\text { size }\end{array}$ & $\begin{array}{l}\text { Number } \\
\text { fledglings }\end{array}$ \\
\hline 1 & 17 & Deciduous & 7 May 1985 & 2 & 2 \\
\hline 2 & 36 & Deciduous & 11 May 1985 & 2 & 2 \\
\hline 3 & 15 & Deciduous & 23 May t985 & 2 & 2 \\
\hline 4 & $2 \cdot 1$ & Deciduous & 28 May 1985 & 2 & 2 \\
\hline 5 & 17 & Deciduous & 17 June 1985 & 1 & $i$ \\
\hline 6 & 60 & Plantation & 19 June 1985 & 2 & 1 \\
\hline 7 & 30 & Plantation & 5 June ro85 & 2 & 2 \\
\hline 8 & 40 & Plantation & 7 June 1985 & 2 & 2 \\
\hline 9 & 41 & Deciduous & 28 June 1985 & 2 & 2 \\
\hline $10^{2}$ & 75 & Evergreen & Unknown & 2 & 0 \\
\hline 11 & 13 & Deciduous & 27 May 1986 & 2 & 2 \\
\hline $12^{2}$ & 11 & Evergreen & Unknown & 2 & 0 \\
\hline $13^{3}$ & 125 & Plantation & 12 June 1986 & 2 & $i$ \\
\hline 14 & 31 & Deciduous & 24 February $198_{7}$ & I & I \\
\hline 15 & 15 & Evergreen & 25 March 1987 & 1 & 1 \\
\hline 16 & 13 & Deciduous & 5 April uo87 & 2 & 2 \\
\hline 17 & 20 & Plantation & 4 April 1987 & 2 & 1 \\
\hline $18^{1}$ & 20 & Plantation & Unknown & 2 & (3) \\
\hline 19 & 75 & Deciduous & 26 April 1987 & 2 & I \\
\hline 20 & 20 & Deciduous & 17 April 1987 & 1 & 1 \\
\hline $2 \mathrm{I}$ & 2 & Deciduous & 7 May 1987 & 2 & 2 \\
\hline 22 & 15 & Deciduous & 22 April 1987 & 2 & 2 \\
\hline 23 & 37 & Evergreen & 9 May 1987 & 2 & 2 \\
\hline
\end{tabular}

"As illustrated in Figure 1.

"Nest predation.

Chick predation.

Nest abandoned.

As defined by Lugo ef al. (1978).

1932, Raynor 1941, Steyn and Myburgh 1975, Berry 1979). In contrast to this pattern in other species, male Nightjars incubated more $(68 \%)$ than females (32\%) (Figure 4). Only in $\mathrm{Ng}$ did the female incubate more (54\%). With the exception of $\mathrm{Ng}_{9}$, no female Nightjar was found incubating during the day. Males sit tightly on the eggs during the day and hold their body pressed to the ground, which enhances their inconspicuousness.

Incubating birds remain on the eggs even when closely approached. However, if approached within a metre, the adult will usually flush from the nest. When flushed, the incubating Nightjar flew up abruptly, landing a few metres from the nest. This display varies in intensity depending on the phase of the incubation period and the frequency of visits by the observers, as it does in other caprimulgid species (Lack 1957, Gramza 1967).

After incubating throughout the day, Nightjar males were relieved at the nest. Nest relief was accompanied by an elaborate nest-relief ceremony. This previously unreported behaviour has not been noted for any other caprimulgid species. Relief at the nest in other caprimulgids simply consists of one member flying off as the relieving bird walks to the eggs and resumes incubation (Raynor 1941). However, I observed nesting Nightjar pairs spend approximately 90 seconds displaying before the relieving bird settled on the eggs. The behavioural 

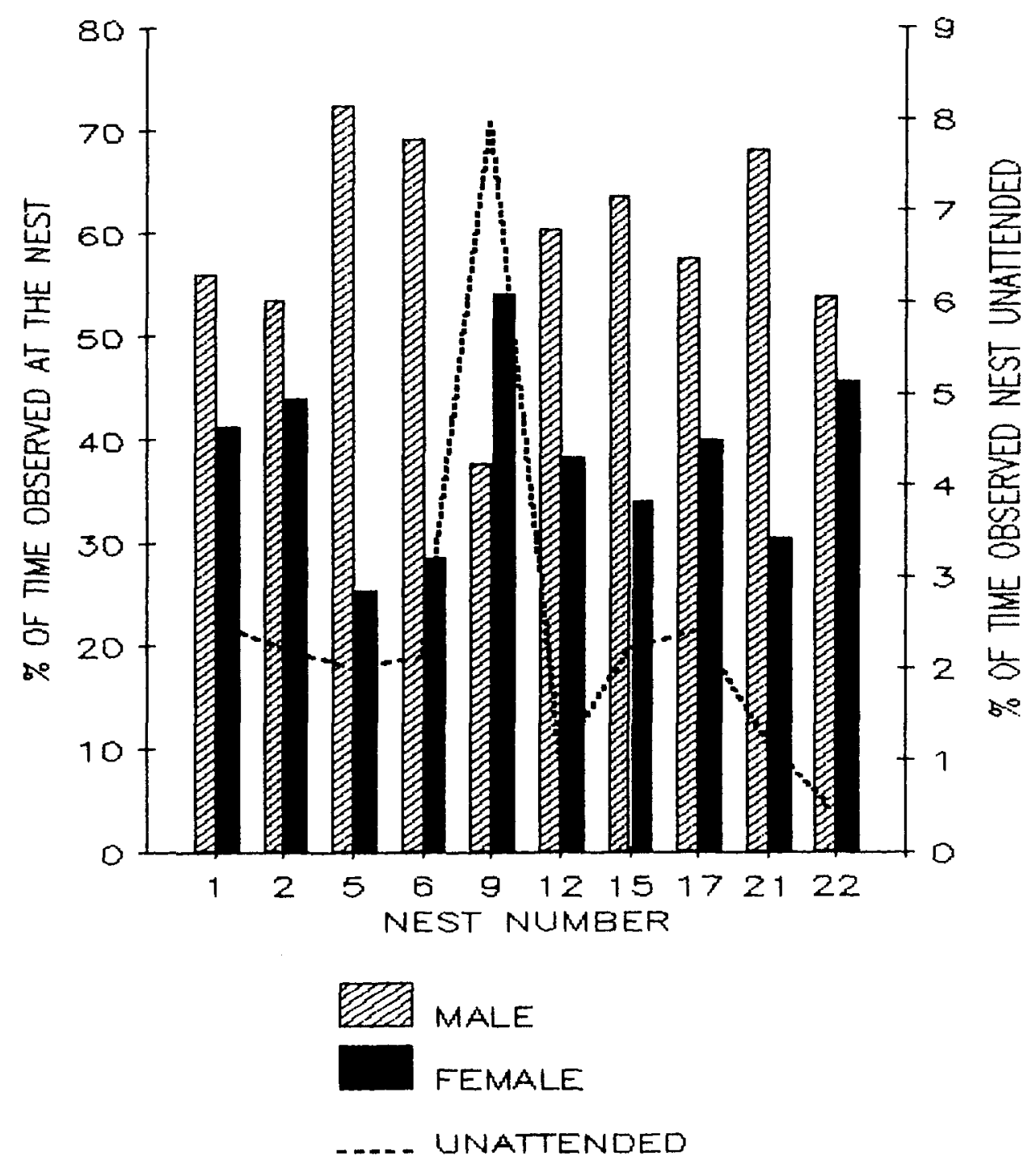

Figure 4. Nest attendance of Nightjar pairs $(n=10)$ monitored from observation blinds at Guánica Forest, Puerto Rico. Nest numbers correspond to those illustrated on Figure 1.

sequence was as follows. As neighbouring males started to sing during early dusk hours, the incubating male became restless and would frequently shift position on the eggs. The female silently flew in and perched on a low branch. Both Nightjars emitted soft, guttural sounds during this time. Suddenly, the male stood and displayed in front of the nest, raising and spreading his tail and with wings outstretched (Figure 5). After the female landed both birds faced each other for 10-15 seconds, and the male vibrated his body and ruffled his feathers as the female spread her tail and drooped her wings. The male then flew off, as the female slowly walked to the nest and resumed incubation. 


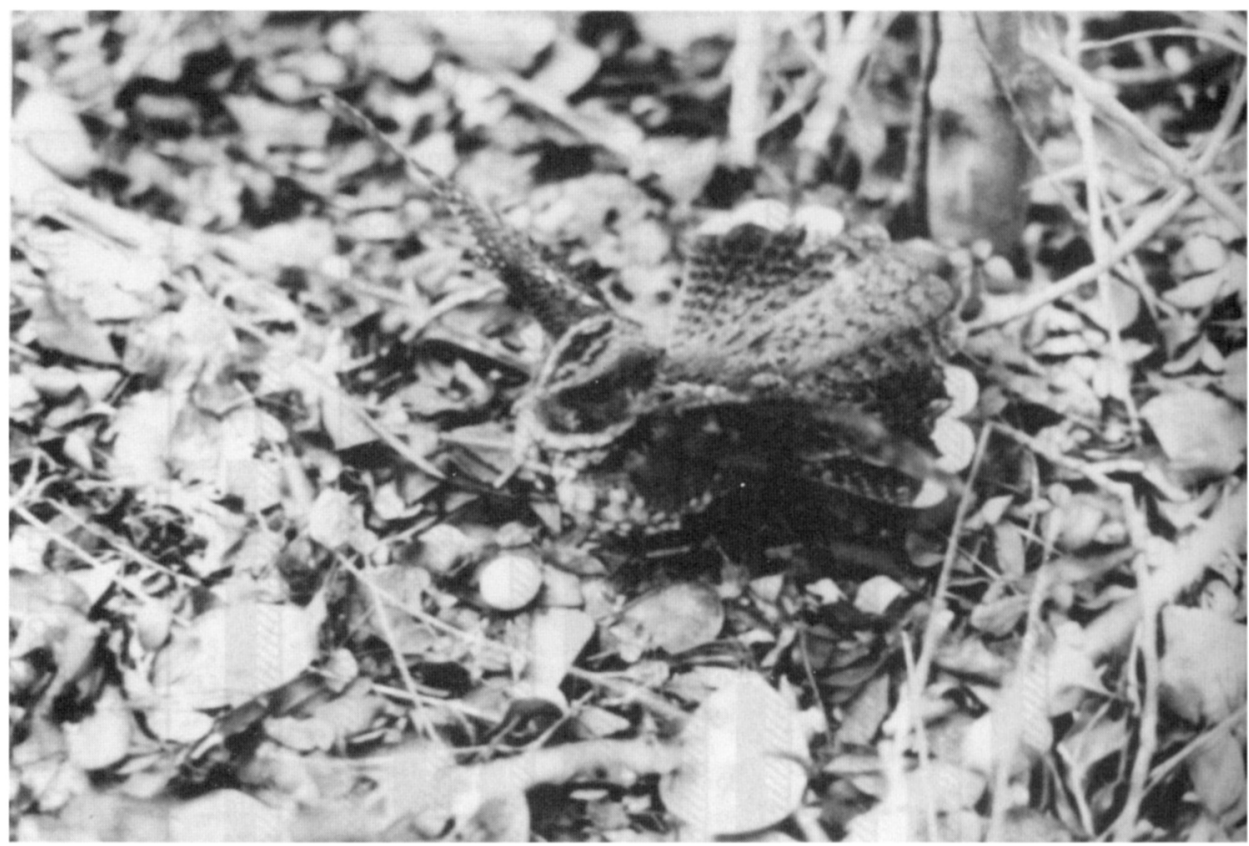

Figure 5. Male Puerto Rican Nightjar engaged in the nest relief ceremony in front of his single egg. The female, who was perched in a low branch nearby, landed in front of the displaying male before relieving. (Photograph by F. J. Vilella.)

Upon being relieved, nesting males flew around their territory singing intensely on favoured perches. Areas of the territory adjacent to singing neighbouring males were visited first. I never observed nesting males to sing while incubating. However, if the female failed to relieve the male during crepuscular periods of peak singing, the male would often fly off to sing and leave the nest unattended. During the study, I noted that nests often remained unattended for more than one hour before a member of the pair returned to incubate. Nests of those pairs monitored were left unattended an average of $2.4 \pm 0.9 \%$ (30 $\mathrm{min} / 24 \mathrm{hrs})$ of the time. Frequently, recently relieved males would return and display to the incubating female once the peak singing period was over. Nevertheless, the female remained sitting until the male flew off. Following the period of singing activity at dawn, males resumed incubation by alighting and displaying to the female, who silently flew off.

Eggs hatch after an 18-20 day incubation period; the incubation period for $70 \%$ of the nests located was 19 days. Hatching occurred from March to July. Hatching was centred around the latter part of the first quarter and during the full moon $\left(\chi^{2}=23.1\right.$, d.f. $\left.=3, p<0.0001\right)$. Brooding was most common during May and June (Figure 3). Chicks hatched on successive days, and during their first 2-3 days appeared very similar to the young of the Eastern Whip-poor-will Caprimulgus vociferus (Tyler 1940).

Between 1985 and 1987 a total of 10 broods were intermittently monitored from the day of hatching to fledging (Table 2). As with incubation, the male is primarily responsible for care of the young. Chicks are fed by regurgitation 
Table 2. Weights at weekly intervals and movements of Nightjar chicks monitored from the day of hatching in Guánica Forest, Puerto Rico.

\begin{tabular}{|c|c|c|c|c|c|c|}
\hline \multirow[t]{2}{*}{ Nest $^{1}$} & \multirow{2}{*}{$\begin{array}{l}\text { Number } \\
\text { chicks } \\
\text { hatched }\end{array}$} & \multicolumn{3}{|c|}{ Weight ${ }^{2}$ (gr) } & \multirow{2}{*}{$\begin{array}{l}\text { Number of } \\
\text { movements }\end{array}$} & \multirow{2}{*}{$\begin{array}{l}\text { Mean distance/ } \\
\text { movement }{ }^{+}(\mathrm{m})\end{array}$} \\
\hline & & Hatch & 7 days & 14 days & & \\
\hline 5 & 1 & 4.2 & 23.8 & 41.6 & 5 & 4.0 \\
\hline 6 & 2 & $4 \cdot 2 / 4 \cdot 1$ & $21.9^{*}$ & 37.8 & 6 & 5.5 \\
\hline 7 & 2 & $4.2 / 4.2$ & $22.5 / 21.8$ & $36.5 / 33.1$ & 6 & $5 \cdot 3$ \\
\hline 11 & 2 & $4 \cdot 2 / 4 \cdot 1$ & $22.3 / 21.8$ & $37.5 / 33.1$ & 7 & 6.4 \\
\hline 13 & 1 & 4.2 & $23 \cdot 5$ & 39.8 & 4 & 6.9 \\
\hline 15 & 1 & $4 \cdot 2$ & 23.2 & 38.1 & 6 & 5.8 \\
\hline 16 & 2 & $4 \cdot 2 / 4 \cdot 2$ & $22.9 / 21.5$ & $36 \cdot 5 / 34 \cdot 3$ & 7 & $4 \cdot 7$ \\
\hline 17 & 2 & $4 \cdot 2 / 4 \cdot 1$ & $22.8 / 21.5$ & $36.5^{*}$ & 7 & 5.2 \\
\hline 19 & 2 & $4 \cdot 2 / 4 \cdot 2$ & $22.8 /^{*}$ & $37 \cdot 3$ & 6 & $5 \cdot 3$ \\
\hline 21 & 2 & $4 \cdot 2 / 4 \cdot 1$ & $23 \cdot 3 / 22.1$ & $36.8 / 33.5$ & 6 & $5 \cdot 5$ \\
\hline
\end{tabular}

${ }^{1}$ As illustrated in Figure 1.

${ }^{2}$ First chick hatched/second chick hatched.

${ }^{3}$ Between 1-14 days old.

${ }^{4}$ Harmonic mean.

- Date after which chick was not seen again.

throughout the night. During twilight hours, both members of the pair alternately fed the young. Brooding males did not sing for prolonged periods of time during twilight hours, and I never heard them singing within $30 \mathrm{~m}$ of the chicks. When a brooding Nightjar was disturbed it engaged in prominent displays, similar to those observed during the incubation phase, except they were more intense and lasted for longer periods of time (Figure 6).

Nightjar chicks averaged $4.13 \pm 0.02 \mathrm{~g}$ when hatched. Chicks were capable of short-distance movements within 24 hours of hatching. Adult Nightjars would land a short distance from the chicks and utter soft clucking sounds to which the chicks responded by pushing themselves forward, using their short wings as "crutches". These initial movements were never greater than $50 \mathrm{~cm}$ from the original nest-site.

The sheaths of the flight-feathers started to appear during the first week, and replaced the cinnamon-coloured down that covered the chicks when hatched. Developing rictal bristles appeared at this time. Chicks averaged $21.1 \pm 5.1 \mathrm{~g}$ after the first week, and during this period frequently moved. Chicks foraged on the ground in the immediate area where they were located, apparently searching the leaf-litter for insects when left alone by the parents during the night hours. Between 7 and 14 days of age, Nightjar chicks assumed an awkward appearance as their feather-sheaths continue to develop. If the brooding adult was flushed at this time, the chicks quickly moved to dense cover and remained motionless while the adult performed distraction displays. Additionally, during this period, chicks were left unattended for prolonged periods ( $>1.5 \mathrm{hrs}$ ) during the night.

By the time the chicks were 14 days old, they averaged $36.6 \pm 2.5 \mathrm{~g}$, and had the adult plumage pattern. They were capable of considerable movement and short flights. During the day, adult birds roosted on the ground during the day next to the chicks. However, if disturbed, the adult flew off without displaying and the chicks flew up to the higher branches of the nearest tree. During the 


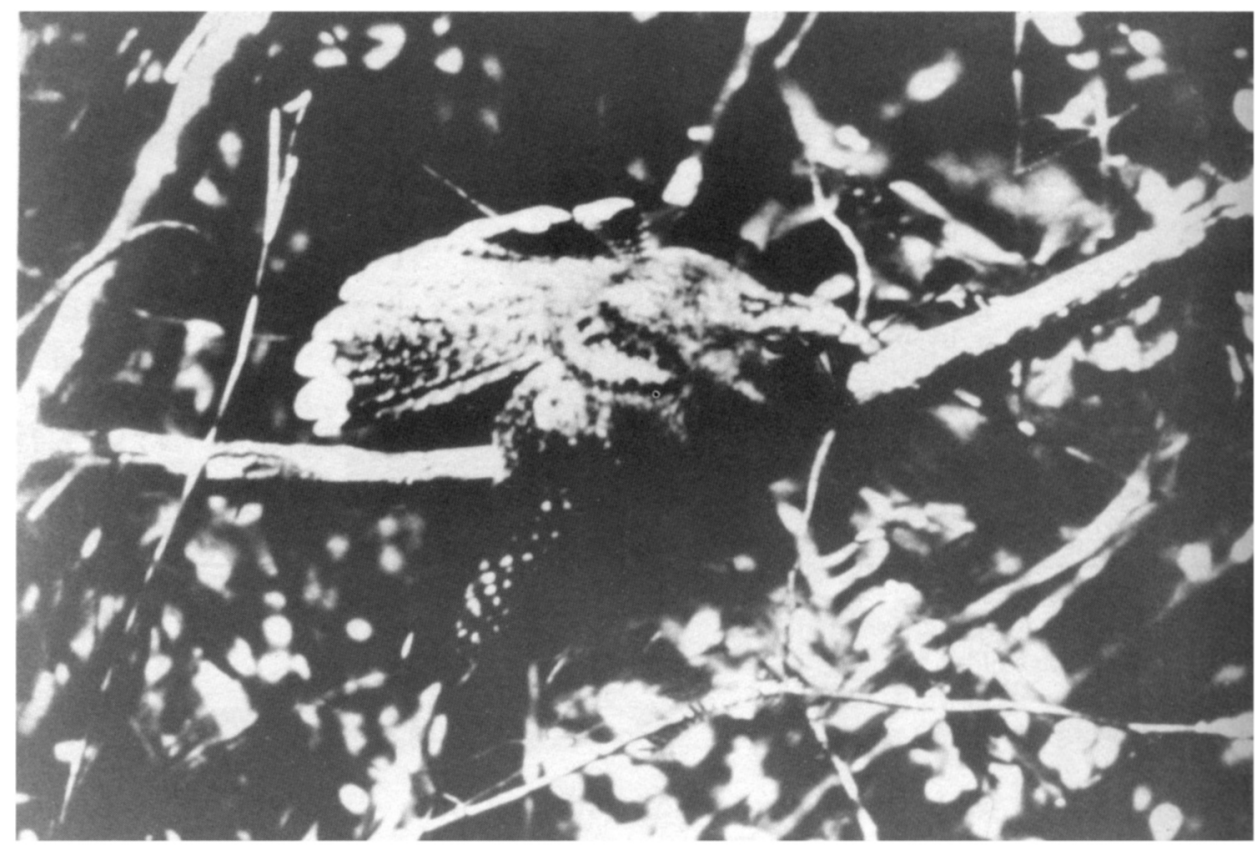

Figure 6. Full distraction display of a brooding male Puerto Rican Nightjar. Notice the white tips of the tail feathers, indicative of males. As the chicks developed, the intensity of this display diminished. (Photograph by F. J. Vilella.)

latter part of the breeding season, fledged young and immature Nightjars sat on the ground at night by the edge of the trails or natural forest openings. From the ground, they made short sallies to capture flying insects and also foraged for terrestrial insects. Immature Nightjars remained on the male's territory for up to a month after fledging.

A total of $87 \%$ of the nests studied were successful in producing at least one fledgling. Three of the 23 Nightjar nests located during the study failed. The incubating male was killed and the eggs destroyed at N10 on 5 June 1986, 10 days after being discovered. The eggs had been crushed and consumed; the predator responsible could have been a feral cat Felis silvestris cattus or a mongoose Herpestes auropunctatus. This nest had been visited the day before in the afternoon and found to be in good condition. Feather remains of the dead adult and eggshells were found the following day just after dawn. This suggests the nest was destroyed during the night. Feral cats at Guánica were most commonly seen during night hours, whereas mongooses are known to be strictly diurnal (Nellis and Everard 1983).

During that same year on 3 July, the clutch of N12 was discovered apparently destroyed by an avian predator. A male was heard singing from the N12 territory later that day; no remains of an adult were found and apparently only the brood was lost. Remains of both eggs were still on the N12 nest-site when discovered; however these had been pecked open and their contents consumed.

The third nest failure occurred during the 1987 breeding season after the incubating male (N18) was captured, fitted with a radio-transmitter and 
released. Although released apparently unharmed, the bird failed to return to the nest. The female was never seen approaching the unattended nest. Although the nest was abandoned, I was able to track the N18 male for over three weeks before the transmitter failed.

Predation attempts on chicks and juvenile Nightjars were observed on two occasions during the course of the study. On 15 August 1985 at 20h45, a juvenile Nightjar flew across the trail about $15 \mathrm{~m}$ ahead. Just before the bird reached the other side of the trail and cover of the forest, a Short-Eared Owl Asio flammeus flew quietly out of the forest and swooped at the young Nightjar. Short-eared Owls are permanent breeding residents at Guánica Forest, utilizing natural forest openings for roosts and nesting on the base of dead Puerto Rican century plants Furcraea tuberosa. On 3 July 1986 when checking N13, I discovered the male Nightjar brooding a two-day-old chick approximately $80 \mathrm{~cm}$ from the nest-site. At the nest-site, a partly pipped egg was found completely covered with ants. The chick apparently had been killed by the ants as it was attempting to emerge from the egg. Apparently, the male moved the surviving chick from the ants' path and avoided the loss of his entire brood.

\section{Movements and activity patterns}

Adult Nightjars were always seen within the forest interior, sometimes near its edge. Two males (N6, N18) were captured and fitted with radio-transmitters during the study. The N6 male was captured after both young had fledged, and the N18 male was captured when it was incubating. Male N6 was tracked for 13 days, while male N18 was tracked for 24 days. A total of 225 locations $\left(\mathrm{N} 6=92, \mathrm{~N}_{18}=133\right)$ were recorded. The maximum move recorded for the N6 male was $270 \mathrm{~m}$. The average distance covered was $57.2 \pm 7.3 \mathrm{~m} /$ movement, and the mean area utilized was $0.3 \pm 0.07 \mathrm{ha} /$ tracking period. Additionally, the N6 male moved an average of $4.2 \pm 1.7$ times/period. The greatest distance covered by the N18 male was $360 \mathrm{~m}$. On average, N18 moved $65.8 \pm 37.5 \mathrm{~m} /$ movement and covered $0.57 \pm 0.3 \mathrm{ha} /$ tracking period. The mean number of movements was $6.7 \pm 3.5$ movements/period. The areas of primary utilization (i.e. home range) encompassed by each Nightjar during the period of transmission were 4.8 ha $(\mathrm{N} 6)$ and 5.6 ha $\left(\mathrm{N}_{1} 8\right)$. The number of movements and the distance covered between movements (pooled data) were significantly higher during twilight than midnight periods $\left(\chi^{2}=21.1\right.$, d.f. $\left.=2, p<0.0001\right)$. Additionally, the number of movements and distance/movement were significantly higher during dusk than dawn hours $(t=7.4, d f=157$, $p<0.0001$ ).

Nightjar males exhibited strong site fidelity. I assume that the distribution of singing males along each trail surveyed varied little during the course of the year and among years. On several occasions as I flagged a trail, previous year flags were adjacent to, sometimes in the same tree, as the flags of the current year. Nests $N_{11}$ and N16 were apparently of the same pair but from different years. N11 was discovered on 27 May 1986, approximately $13 \mathrm{~m}$ inside the forest (Figure 1). The following year on 5 April, N16 was located at the exact same site. A male was heard singing from this territory throughout 1986-1987, and I assumed both nests involved the same breeding pair. 
I was able to observe Nightjars foraging at Guánica Forest many times during the study. These observations were gathered during twilight and night periods. The nightscope was utilized during periods of darkness when sufficient moonlight was available. Like other caprimulgids (Tyler 1940), Nightjars were seen to visit favourite perches at night. Nightjars perched on branches approximately $2.5 \mathrm{~m}$ above the forest floor. From here, they sallied after insects and returned to the same branch. On several occasions, a Nightjar was seen returning to the branch with a captured insect in its bill. These were usually large insects, probably moths or beetles. After landing, the bird would hold its head upright, shake and swallow the prey.

Nightjars also fed on insects attracted to artificial light sources. At least three different male Nightjars frequently visited the trees surrounding the management officer's house at Guánica Forest. A bright lamppost in front of the house attracted insects from a large area. Nightjars sallied out, keeping their bill open as they flew through clouds of small insects. Scarabaeid beetles (e.g. Homara texana) often hit the lamp and fluttered to the ground. Nightjars landed and with outstretched wings, picked the beetles from the ground. Other bird species such as Red-legged Thrush Turdus plumbeus and Grey Kingbird Tyrannus dominicensis as well as several species of bats, were also attracted to this food source.

\section{Discussion}

Nightjar males sing throughout the year at Guánica Forest, but a distinct seasonal pattern in the total number of singing birds and in the duration of the calling period was observed. Both biological and environmental factors contribute to the observed pattern. Cessation of nesting is known to accompany a decrease in singing ( $\mathrm{O}^{\prime}$ Connor 1980). Additionally, rainy nights with heavy cloud-cover were frequent during this time of the year (August-October) as tropical depressions moved across the Caribbean. Caprimulgids sing little under these atmospheric conditions (Cooper 1981).

The sedentary nature of caprimulgids has been documented (Berry and Bibby 1981, Cooper 1981). The number of movements and distance covered by the male Nightjars fitted with radio-transmitters (N6, N18) suggested there is strong site fidelity by males of this species during the nesting season. The maximum distances covered by these two males during the life of the transmitters was $270 \mathrm{~m}$ and $360 \mathrm{~m}$ respectively. These compare with the maximum distances reported (Jackson 1985) for marked Fiery-necked Nightjars Caprimulgus pectoralis in Zimbabwe $(376 \mathrm{~m})$. In Zimbabwe, most male Fiery-necked Nightjar recaptures occurred within $100 \mathrm{~m}$ of where the birds were banded (Jackson 1984,1985 ). The areas calculated as being used by both N6 (4.8 ha) and N18 ( $5.6 \mathrm{ha}$ ) were similar to the areas calculated from density estimates obtained from call counts for that section of Guánica Forest (Vilella and Zwank 1993a).

Capturing additional nesting Nightjars at Guánica Forest was impractical. The male at $\mathrm{N}_{1} 8$ did not return to the nest after being captured and it was not appropriate to risk further nest abandonment by an endangered species. The abandoned clutch was collected and placed in the egg collection at the 
Ornithology Division of the Louisiana State University Museum of Natural Science.

At Guánica Forest, the Nightjar's breeding season extended from late February to late July, but most nesting and fledging activity occurred from April to June. The breeding season starts two months earlier than previously reported (Kepler and Kepler 1973).

Lack (1930) demonstrated that the European Nightjar C. europaeus has two broods a season in England; Jackson (1985) documented double-brooding in the Fiery-necked Nightjar and Mozambique Nightjar C. fossii in Zimbabwe. In Guánica Forest the length of the breeding season (more than four months) and the appearance of new nests $(\mathrm{Ng})$ late in the season would be consistent with the occurrence of double-brooding, but I found no concrete evidence of this.

Incubating and brooding were mostly performed by the male, although female Nightjars would occasionally incubate and brood during night hours. Occasional incubation by male Eastern Whip-poor-wills, a close relative of the Nightjar, has previously been reported (Babcock 1975). In the Blackish Nightjar C. nigrescens both members of the pair share parental duties (Roth 1985). Jackson (1985) reported that in the Fiery-necked Nightjar the male incubates and broods at night and the female does by day.

At present, the existing information cannot explain the marked differences in parental attentiveness between the Nightjar and other congeners. Additional studies using marked individuals would be needed to elucidate the mechanisms which may regulate the mating and parental care systems in the Nightjar. Female Nightjars, however, are very secretive animals. They are not commonly found within the male's territory during daylight hours and are only occasionally seen away from parental duties during the night. It would require considerably more effort than that invested in this study to capture and mark a sufficiently large sample of breeding Nightjars of both sexes, in addition to the risk of nest abandonments by some disturbed pairs. At present, I could speculate only that a skewed sex ratio or some type of non-territorial polyandry (Oring and Lank 1986) may be responsible for both the elaborate nest-relief ceremony of males and the nest-attendance patterns of females.

Most breeding females laid their eggs during low moonlight conditions and hatching occurred during the periods of greatest available moonlight. Thus it appeared that in a nocturnal, visually oriented species like the Nightjar, breeding pairs were able to synchronize the first two weeks of the nestlings' lives with the greatest amount of moonlight available for foraging.

Mills (1986) investigated the movements and behaviour of radio-tagged Eastern Whip-poor-wills in Canada and found strong lunarphilia, with significantly higher levels of locomotory, vocal, and nest activity during twilight and bright moonlight than under moonless conditions. For caprimulgids, the first two weeks after egg hatching are the most sensitive for nestling survival (Lack 1930). The semi-precocial young of the Nightjar are fledged by the fourteenth day; thus, as the lunar month entered the following dark period, the independence of the young alleviated the burden on the parents.

Predation of adult Nightjars and their nest contents was uncommon. Feral cats were occasionally seen along the edge of forest trails during night hours. Mongoose abundance is very low in the forested uplands of Guánica Forest 
where Nio was located, ranging from o to 1.1 mongoose/ha (Vilella and Zwank 1993b).

At Guánica Forest, the Pearly-eyed Thrasher Margarops fuscatus is an active ground forager and nest predator that is commonly seen taking eggs and young of smaller passerines such as the Bananaquit Coereba flaveola (pers. obs.). The Red-legged Thrush also commonly forages on the forest floor (pers. obs.); however, its diet consists mainly of insects and fruit (Biaggi 1974). The latter species has not been reported to prey on the eggs and/or young of other avian species.

Conservation of the Nightjar greatly depends on the continued protection of the dry limestone and lower cordillera forest reserves - Guánica and Susúa Forests - where the species presently occurs. These reserves, managed by the DNER Forestry Division include approximately $53 \%$ of the species's current range (Vilella and Zwank 1993a). However, development pressures exist in areas surrounding these reserves and even within the reserves themselves. Projects ranging from exclusive resorts to municipal landfills have been proposed for areas adjacent to these reserves. The opening and paving of Guánica Forest's system of roads has been proposed on several occasions by the municipal governments of adjacent towns (Canals 1990). This proposal is of particular concern since these roads would cut across the limestone platform where the upland dry forest associations are found and, consequently, where the majority of the Nightjar nesting activity was documented (Figure 1 ).

These projects would all involve permanent alteration of presently occupied Nightjar habitat. The sedentary nature of this species and its need for a mature, closed-canopy forest environment provides little room even for what project developers may visualize as minor habitat alterations. Furthermore, the continuing deforestation and fragmentation of privately owned tracts of coastal dry limestone forest still remain as the single most important limiting factors affecting the species's present status and eventual recovery. Specific conservation needs include maintenance of the present state of both Guanica and Susúa Forests, and the acquisition of private lands adjoining both reserves as well as lands in the Guayanilla Hills, an area containing the largest tracts of privately owned mature dry forests (Vilella and Zwank 1993a). Reforestation practices using native and commercial tree species to restore highly disturbed areas within and outside dry limestone forest reserves should be encouraged.

Some areas in Guánica Forest are characterized by dense stands of mid-storey (e.g. Croton rigidus) and over-storey species (e.g. Prosopis juliflora) that suggest intense disturbance in the past from forest clearance and overgrazing. These areas are not favoured by Nightjars as nesting habitat, yet they are common within privately owned forests in south-west Puerto Rico. However, Nightjars readily utilize abandoned tree plantations in the uplands of Guánica Forest within the deciduous and evergreen forest types. These areas are characterized by an over-storey dominated with the plantation species mahogany Sweetenia mahogany and logwood Haematoxylum campechianum. Owing to the allelopathic nature of these tree species, these areas are characterized by an open mid-storey, and also have a high production of leaf-litter (Lugo et al. 1978).

A restoration programme where forest tracts are planted using fast-growing plantation species mixed with native species (e.g. Pisonia albida, Bucida buceras) 
would provide good-quality Nightjar nesting habitat. These could be established within the presently existing reserves or in newly formed reserves (i.e. Guayanilla Hills). Such conservation practices, together with the application of existing environmental and planning regulations, will be essential to ensure the continuing existence of the Nightjar and its dry forest environments.

\section{Acknowledgements}

I am grateful to Miguel E. Canals, DNER Management Officer at Guánica Forest, for field assistance and helpful comments. Funding was provided by the FWS through the Louisiana Cooperative Fish and Wildlife Research Unit, School of Forestry, Wildlife and Fisheries, Louisiana State University. Phil Zwank provided technical guidance and friendly support throughout the study. I am indebted to two anonymous reviewers for comments which greatly improved the manuscript. The following individuals assisted with nest searches and monitoring during the course of this study: Miguel E. Canals, José A. Colón, Tristan J. Davis, Baudilio Hernández, Robert E. Noble, Germán Padilla, Ana M. Román and Elvin Silva.

\section{References}

Babcock, R. E. (1975) Another instance of incubation by a male Whip-poor-will. Wilson Bull. 87: 284 .

Berry, R. (1979) Nightjar habitats and breeding in East Anglia. Brit. Birds 72: 207-218.

Berry, R. and Bibby, C. J. (1981) A breeding study of nightjars. Brit. Birds 74: 161-169.

Biaggi, V., Jr. (1974) Las aves de Puerto Rico. San Juan: Editorial Universitaria, Universidad de Puerto Rico.

Canals, M. E. (1990) El futuro del Bosque de Guánica como una unidad efectiva de conservación. Acta Cientifica 4 (1-3): 109-112.

Collar, N. J., Gonzaga, L. P., Krabbe, N., Madroño Nieto, A., Naranjo, L. G., Parker, T. A. and Wege, D. C. (1992) Threatened birds of the Americas: the ICBP/IUCN Red Data Book. Cambridge, U.K.: International Council for Bird Preservation.

Cooper, R. J. (1981) Relative abundance of Georgia caprimulgids based on call-counts. Wilson Bull. 93: 363-371.

Diaz, C. (1983) Recovery plan for the Puerto Rican Whip-poor-will Caprimulgus noctitherus. Atlanta: U.S. Fish and Wildlife Service.

Dixon, K. R. and Chapman, J. A. (1980) Harmonic mean measure of animal activity areas. Ecology 61: 1040-1044.

Ewel, J. J. and Whitmore, J. L. (1973) The ecological life zones of Puerto Rico and the U.S. Virgin Islands. Forest Service Research Publ. ITF-18, USDA.

Fowle, C. D. and Fowle, A. M. (1954) Observations at a Whip-poor-will's nest. Canad. Field-Nat. 68: 37-39.

Gramza, A. F. (1967) Responses of brooding nighthawks to a disturbance stimulus. Auk 84: $72-86$.

Jackson, H. D. (1984) Capture/recapture data on the nightjars of Ranelia Farm, Zimbabwe. Safring Neros 14(1): 43-50.

Jackson, H. D. (1985) Aspects of the breeding biology of the Fierynecked Nightjar. Ostrich Suppl. 56: 263-276.

Johnson, T. H. (1987) Biodiversity and conservation in the Caribbean: profiles of selected islands. Cambridge, U.K.: International Council for Bird Preservation (Monogr. 1). 
Joyner, S. P. (1985) SAS/STAT guide for personal computers. Version 6 ed. Cary, N.C.: SAS Inst., Inc.

Kepler, C. B. and Kepler, A. K. (1973) The distribution and ecology of the Puerto Rican Whip-poor-will. Living Bird I: $5 x-60$.

Lack, D. (1930) Double-brooding of the nightjar. Brit. Birds 23: 242-244.

Lack, D. (1932) Some breeding-habitats of the European Nightjar. Ibis (13)2: 266-284.

Lack, D. (1957) Notes on nesting nightjars. Brit. Birds 50: 273-277.

Lugo, A. E., González-Liboy, J. A., Cintrón, B. and Dugger, K. (1978) Structure, productivity, and transpiration of a subtropical dry forest in Puerto Rico. Biotropica $10(4): 278-291$.

Mills, A. M. (1986) The influence of moonlight on the behavior of goatsuckers (Caprimulgidae). Auk 103: 370-378.

Nellis, D. W. and Everard, C. O. R. (1983) The biology of the mongoose in the Caribbean. Stud. Fauna Curacao \& Carib. Isl. 64: 1-62.

Noble, R. E., Vilella, F. J. and Zwank, P. J. (1986b) Apuntes sobre el anidamiento del guabairo. Carib. J. Sci. 22(3-4): 223.

O'Connor, R. J. (1980) The growth and development of birds. New York: Wiley Interscience.

Oring, L. W. and Lank, D. B. (1986) Polyandry in Spotted Sandpipers: the impact of environment and experience. Pp.21-42 in D. I. Rubenstein and R. W. Wrangham, eds. Ecological aspects of social evolution. New Jersey: Princeton University Press.

Raynor, G. S. (1941) The nesting habits of the Whip-poor-will. Bird-banding 12: 98-104.

Reynard, G. B. (1962) The rediscovery of the Puerto Rican Whip-ponr-will. Living Bird 1: $51-60$.

Roth, P. (1985) Breeding biology of the Blackish Nightjar Caprimulgus nigrescens in western Brazil. Gerfaut 75: 253-264.

Steel, R. G. D. and Torrie, J. H. (1980) Principles and procedures of statistics: a biometrical approach. Second edition. New York: McGraw-Hill.

Steyn, P. and Myburgh, N. J. (1975) Notes at a Fierynecked Nightjar's nest. Ostrich Suppl. 9: 179-188.

Tyler, W. M. (1940) Eastern Whippoorwill. Pp.163-183 in A. C. Bent, ed. Life histories of North American cuckoos, goatsuckers, hummingbirds, and their allies. U.S. Natn. Mus. Bull. 176.

Vilella, F. J. and Zwank, P. J. (1993a) Geographic distribution and abundance of the Puerto Rican Nightjar. J. Field Orn. 64: 223-238.

Vilella, F. J. and Zwank, P. J. (1993b) Ecology of the small indian mongoose in a coastal dry forest of Puerto Rico where sympatric with the Puerto Rican Nightjar. Carib. J. Sci. 29(1-2): $24-29$.

\section{FRANCISCO J. VILELLA}

U.S. National Biological Service, Mississippi Cooperative Fish and Wildlife Research Unit, P.O. Drawer BX, Department of Wildlife E Fisheries, Mississippi State University, Mississippi, MS 39762, U.S.A. 